\title{
Comparison of Knowledge Levels of Nursing Students and Clinical Nurses Related to Hemogivigilance: Preliminary Work to Develop a Measurement Tool
}

\author{
Hemşirelik Öğrencileri ve Klinik Hemşirelerin Hemovijilans ile İlgili Bilgi \\ Düzeylerinin Karşılaştırılması: Ölçüm Aracı Geliştirme Ön Çalışması
}

(D) Ayşegül KOÇ, id Esra TAYAZ

Ankara Yıldırım Beyazıt University, Department of Nursing, Ankara, Turkey

\section{ABSTRACT}

Objective: In this study, it was aimed to evaluate the knowledge level of the nursing students and clinical nurses who have applied the clinical practice related to hemogivigilance.

Methods: This research was comparative and cross-sectional in design. The measurement tool consisted of two parts in the collection of research data. The first part included the demographic variables, and the second part consisted of "hemovigilance information index" created by the researcher. The sample was completed with 146 nursing students and 137 clinical nurses working in the hospital for clinical practice, who volunteered to participate in the research. Ethical permissions were obtained from the Ankara Yıldırım Beyazıt University Ethics Committee to conduct the research.

Results: It was concluded that there was a significant relationship between having knowledge about hemovigilance or hemovigilance nursing, thinking of being competent about hemovigilance, selfsufficiency about blood transfusion, having knowledge about the meaning of the term "near miss" about hemovigilance, knowledge about the transfusion follow-up form, late and early reactions that might occur as a result of blood transfusion, and the number of correct answers $(\mathrm{p}<0.05)$.

Conclusion: It was concluded that the knowledge level increased as the clinical experience increased in nursing student. It was
ÖZ

Amaç: $\mathrm{Bu}$ araştırmada, klinik ders uygulamasını yapmış hemşirelik öğrencilerinin ve klinik hemşirelerinin hemovijilans ile ilgili bilgi düzeylerinin değerlendirilmesi amaçlanmıştır.

Yöntemler: $\mathrm{Bu}$ araştırma karşılaştırılmalı ve kesitsel olarak tasarlanmıştır. Araştırma verilerinin toplanmasında kullanılan ölçüm aracı iki bölümden oluşmaktadır. Birinci bölüm demografik değişkenleri içermekte, ikinci bölüm ise araştırmacı tarafından oluşturulmuş "hemovijilans bilgi indeksi” tamamlanmıştır. Klinik uygulama için hastanede çalışan, araştırmaya katılımı gönüllü olan 146 hemşirelik öğrencisi ve 137 klinik hemşiresi ile örneklem tamamlanmıştır. Araştırmanın yapılabilmesi için etik izinler Ankara Yıldırım Beyazıt Üniversitesi Beşeri ve Sosyal bilimler Etik Kurulu'ndan alınmıştır.

Bulgular: Hemovijilans ya da hemovijilans hemşireliği hakkında bilgi durumu, hemovijilans konusu hakkında yeterli olduğunu düşünme, konu ile ilgili eğitim gerekliliği, hemovijilans ile ilgili "ramak kala" teriminin anlamı, transfüzyon izlem formu hakkında bilgi durumu ve kan transfüzyonu sonucunda oluşabilecek reaksiyonlar hakkında bilgi sahibi olma durumu ile doğru sayısı arasında anlamlı farklılık olduğu sonucuna ulaşılmıştır $(\mathrm{p}<0,05)$.

Sonuç: Öğrenci hemşirelerde klinik deneyim arttıkça bilgi düzeyinin arttığı sonucuna varılmıştır. Klinik hemşirelerin hemovijilans ile

Address for Correspondence: Esra TAYAZ, Ankara Yıldırım Beyazıt University, Department of Nursing,

Received: 04.05.2020 Ankara, Turkey

E-mail: esratayaz@gmail.com ORCID ID: orcid.org/0000-0001-6614-8401

Accepted: 30.09 .2020

Cite this article as: Koç A, Tayaz E. Comparison of Knowledge Levels of Nursing Students and Clinical Nurses Related to Hemogivigilance: Preliminary Work to Develop a Measurement Tool.

Bezmialem Science 2021;9(4):472-80. 
determined that clinical nurses had a high level of knowledge related to hemovigilance and students did not. In-service trainings were found to be sufficient in this regard.

Keywords: Hemovigilance, nurse, blood and blood products, transfusion, hemovigilance nursing ilgili bilgi düzeylerinin yüksek olduğu, öğrencilerin ise istenen düzeyde olmadığı belirlenmiştir. Hizmetiçi eğitimlerin bu konuda yeterli olduğu görülmüştür.

Anahtar Sözcükler: Hemovijilans, hemşire, kan ve kan ürünleri, transfüzyon, hemovijilans hemşireliği

\section{Introduction}

Since collecting, storing, transporting and transfusing blood and blood products for therapeutic purposes within the scope of health care services is an important service, it should be carried out in accordance with the standards (1). In our country, the current regulations regarding the blood supply system have been made within the scope of the main directive numbered 2002/98/ EC, which is also included in the closing criteria of the $28^{\text {th }}$ chapter titled "Protection of the Consumer and the Health of the Consumer" (2). Establishing standardized definitions for adverse events is crucial to achieving the goal of all surveillance systems (3). In this direction, in the main directive, hemovigilance is defined as "a series of surveillance that covers the entire transfusion chain, including the follow-up after blood collection and delivery to the recipient, collecting and evaluating all kinds of undesirable and unexpected effects arising from the use of blood products, preventing these events and preventing their reoccurrence" (4).

The first official studies on hemovigilance started with the establishment of the blood monitoring system by the "Blood Transfusion Committees" in France in 1991. It was implemented in Canada in 1997 after the Krever report. With the establishment of SHOT (serious hazards of transfusion) in 1997 in England, notifications of hemovigilance began. With the establishment of European Hemovigilance Network in 1998, an international analysis platform was formed. The European Blood Directive 2002/98/EC was published on 8 February 2003 (4). In this directive, on October 1, 2005, regulations were made on traceability, serious side effects and quality and standards of blood institutions. In 2005, many countries outside of Europe developed their national hemovigilance systems and became involved in this communication network. In 2006, a hemovigilance program was established in the USA with the American Association of Blood Banks. Hemovigilance information exchange has been continuing at the international level with International Hemovigilance Network since 2009 (5). Studies have been initiated in our country in line with the "EU legislation to adapt", and the National Hemovigilance Guide was created in 2013 and published in 2016 (2).

The aim of hemovigilance is to determine the cause of unexpected situations in blood transfusion and to prevent their reoccurrence, and as a result, to ensure safe blood transfusion (6). For this purpose, issues such as inadequate blood supply structure, insufficient blood supply, increased need, unequal distribution, weak quality systems, risks of infection transmitted by transfusion, and inappropriate use of blood products are priorities in ensuring blood transfusion safety, especially in healthcare services in developing countries (7). Hemovigilance is an important part of the quality system for blood transfusion. It includes methods for identifying errors, adverse events, and reactions, such as alert systems, complaint investigation, traceability systems, notification systems, and application controls (6).

Situations related to the collection, testing, processing, storage, distribution of blood and blood products and which can cause death, permanent and significant disability, disability, hospitalization or prolonged hospital stay in individuals as a result of transfusion of affected products are defined as serious adverse events. Serious undesirable effects and adverse events that occur in the patient during and after blood and blood product transfusion form the basis of the hemovigilance system and must be reported (8) These are;

- Early undesirable serious effects are hemolysis during transfusion, non-hemolytic fever reaction, rash, erythema, urticaria, anaphylactic shock, bacterial contamination, and transfusion-induced acute lung injury.

- Delayed undesirable serious effects are hemolysis, transfusion-associated graft versus host disease, posttransfusion purpura, and elevation in ALT level.

- Virus, parasite or prion contamination.

- Development of alloimmunization against erythrocyte, human leukocyte antigen or platelet antigens. At the same time, undesirable events may occur in the donor (9).

- Hemovigilance is a control system that every healthcare worker responsible for transfusion of blood and blood products should know. Nurses are active members of this system. The role of nurses in hemovigilance is clearly stated in the "National Guide to Hemovigilance" published in 2016. These roles are;

- Every personnel with duties and responsibilities related to transfusion can make notifications about hemovigilance. The hemovigilance officers of the relevant clinics and the hospital hemovigilance nurse are responsible for making these notifications appropriately.

- The hemovigilance nurse checks whether the forms submitted to him/her are filled in appropriately and completely and reports the situation to the hemovigilance committee. 
- In case of a problem with transfusion, if the hemovigilance nurse receives information from the responsible physician that the problem is due to non-transfusion reasons, he/she notifies the hemovigilance committee.

- The nurse or doctor working in the relevant clinic is responsible for the hemovigilance clinic. He/she is responsible for transmitting the Transfusion Monitoring Form of the patients and other data requested for the sustainability of the hemovigilance system to the hemovigilance nurse.

- The hemovigilance nurse organizes trainings.

- The hemovigilance nurse informs the hemovigilance committee about the activities (2).

\section{Definition of the Problem}

Definitions are available for a better understanding of hemovigilance. These are adverse event, serious adverse event, serious uneventful transfusion errors, incorrect transfusion, near miss, adverse reaction, serious adverse reaction, patient-to-donor tracking (Trace-back), donor-to-patient tracking (Look-back), recall, return, and association (2). Clear definitions of the concept of hemovigilance are important for both reporters and those who will analyze reports. Reporting adverse events as soon as possible is essential for quality assurance. Serious adverse events should be reported promptly. Hemovigilance systems provide rapid assessment of serious reports by the hemovigilance task group and additional information requested shortly after reporting. The reporter sometimes needs advice on root cause analyzes and corrective and preventive measures. Health professionals in the hemovigilance committee can provide advice and assistance (10).

It is clear that hemovigilance systems and staff can help collect and analyze the necessary data. Training of hospital transfusion committees, transfusion workers, clinicians and laboratory personnel play an important role in controlling the hemovigilance systems of transfusion units. In summary, optimal use of the hemovigilance system, consensus, common criteria, analysis and regulatory measures are required for the periodic evaluation of hemovigilance studies. At the same time, these studies can support developments (11).

Due to the recent history of hemovigilance, there is a lack of information among healthcare professionals (12). In the healthcare field, the term hemovigilance focuses on transfusion. However, the transfusion constitutes a part of the hemovigilance (4). Studies in the literature focuse on transfusion. Studies involving all components of hemovigilance are insufficient. For this reason, the level of knowledge of healthcare workers on hemovigilance in studies is compared with studies on transfusion (13). Studies emphasized that the knowledge levels of both nurses and nursing students about hemovigilance were insufficient (13-15). Similar results were observed in studies conducted with physician groups (16). For this reason, effective training of healthcare professionals on hemovigilance during clinical or school periods is necessary for quality systems, patient safety, and reduction of malpractices. A structured measurement tool is needed to monitor the process, to feed back when necessary, and to measure the success of the trainings. In this study, it was aimed to determine the knowledge levels of nursing students and clinical nurses who practiced clinical courses for knowledge, skills and experience, and to create an applicable semi-structured scale. Hemovigilance is accepted as a new term in the world and in our country. For this reason, the literature on this subject is not sufficient. In this direction, our study question was "How is the knowledge level of nursing students and clinical nurses about hemovigilance and related concepts?".

\section{Methods}

\section{Research Type}

In this study, a comparative, cross-sectional study was conducted in order to evaluate the knowledge levels of nursing students and clinical nurses about hemovigilance who did clinical course practice.

\section{Universe Sample Selection}

The population of the research consisted of all nursing students studying at a state university in Ankara and all clinical nurses working in a public hospital. In the study, 146 nursing students and 137 clinical nurses who agreed to participate in the study on a voluntary basis were included without choosing a sample.

\section{Data Collection Tool}

Demographic Data Form: The data form created by the researchers was used. In this form; age, gender, presence of smart device, duration of daily use of smart device, monthly internet usage quota, research related to the occupation, information about hemovigilance and where this information was obtained, and level of knowledge about hemovigilance and training on this subject, were recorded. In the form, nursing students were asked what grade they were in, while nurses were asked in which clinic they worked.

Hemovigilance Information Index: It was created by the researchers in line with the literature. Seven of the questions $(1,2,12,13,15,17,20)$ were asked to measure attitude. The remaining questions were directed to the students in order to measure the level of knowledge. The answers given to these questions, which we directed to determine the level of knowledge, were evaluated.

Obtaining Expert Opinion/Scope Validity Index: Items created for the hemovigilance information index were examined by a total of 10 experts in the field of nursing. The SVI values of the expressions for the created knowledge index were found to be between 0.80 and 1.00 , and the average SVI value was found to be 0.92 . In line with expert opinions; some of the items that were not understood, had similar meanings, contained more than one judgment and were stated not to measure attitude were corrected, and some items were removed completely. The form took its final version after expert opinions. 


\section{Application}

Data collection tools were applied at the end of a suitable course determined according to the curriculum of the students and it took approximately 20 minutes for each form to collect the data. It was applied to the nurses in a face-to-face manner during working hours after obtaining the institutional permissions. It took about 10 minutes to fill out the questionnaire.

\section{Ethical Aspect of Research}

In order to carry out the research, permission was obtained from the institution where the study was conducted and approval from the Ankara Yıldırım Beyazıt University Ethics Committee (29.05.2019/decision no: 51) was obtained. Data were collected in accordance with the Declaration of Helsinki. Participants were informed about the purpose of the research, its content and the way the data were collected. Participants were given confidence that their participation in the study was voluntary, that their information would be kept confidential, and that they could withdraw from the study at any time.

\section{Statistical Analysis}

The IBM SPSS Statistics 22.0 (IBM Corp. Released 2014. IBM SPSS Statistics for Windows, Version 22.0. Armonk, NY: IBM Corp.) was used to evaluate the data. Non-parametric tests were used for statistical analysis since the data did not show normal distribution. Percentage, frequency and mean were used for descriptive statistics Kruskal-Wallis H, Mann-Whitney U, t-test and chi-square test were used to evaluate the data. The results were evaluated within the $95 \%$ confidence interval. Statistical significance level was accepted as $\mathrm{p}<0.05$.

\section{Results}

The ages of the nurses participating in the study ranged from 20 to 54 , with an average of $32.17 \pm 8.43$. The demographic data of the participants are given in Table 1 . Women constitute the majority of the participants in both groups. Of the students $32.19 \%$ were first year students, and $43.06 \%$ of the nurses were working in internal medicine units. The highest use of smart devices by both groups was found in 2-4 hours, and the database they used for professional research was Google scholar. While the monthly internet usage quota of the students was $4-6 \mathrm{gb}$ (Gigabytes), it was $10 \mathrm{gb}$ or above in the nurses. Nurses had more knowledge about hemovigilance or hemovigilance nursing, and while students obtained this information via the internet, nurses obtained this information via in-service training. Both groups stated that the students did not have sufficient knowledge about hemovigilance and that education on this subject was important. The numbers of correct answers of clinical nurses and student nurses regarding hemovigilance are given in Table 2.

When the nursing students were examined, it was determined that there was a significant difference between the class variable and the number of correct answers. It was determined as a result of statistical tests that this difference was due to the fact that the number of correct answers of $1^{\text {st }}$ year students was lower than that of $3^{\text {rd }}$ and $4^{\text {th }}$ year students. It was concluded that there was a significant relationship between having knowledge about hemovigilance or hemovigilance nursing, thinking of being competent about hemovigilance, self-sufficiency about blood transfusion, having knowledge about the meaning of the term "near miss" about hemovigilance, knowledge about the transfusion follow-up form, late and early reactions that might occur as a result of blood transfusion, and the number of correct answers $(\mathrm{p}<0.05)$.

When the clinical nurses were examined, it was determined that there was a significant difference between the units they worked in and the number of correct numbers. It was determined as a result of statistical tests that this difference was due to the fact that the correct number of answers of the nurses working in emergency service was higher than those working in surgical units and intensive care units. It was concluded that there was a significant relationship between having knowledge about hemovigilance or hemovigilance nursing, thinking of being competent about hemovigilance, self-sufficiency about blood transfusion, having knowledge about the meaning of the term "near miss" about hemovigilance, knowledge about the transfusion follow-up form, late and early reactions that might occur as a result of blood transfusion, and the number of correct answers $(\mathrm{p}<0.05)$.

\section{Discussion}

Individuals who agreed to participate in our study were examined in two groups as nursing students and clinical nurses. Nursing students made up $51.59 \%$ of the sample, while clinical nurses made up $48.41 \%$ of the sample. Students participating in the study covered all classes, while nurses were working in internal medicine units $(43.06 \%)$, surgical units $(30.66 \%)$, intensive care $(13.87 \%)$ and emergency services $(12.41 \%)$. In the study conducted by Jimenez-Marco et al. (17) on hemovigilance, they reported that the nurses worked in surgery service $(27.27 \%)$, internal medicine service $(22.04 \%)$, emergency service $(16.8 \%)$, blood bank (11.85\%) and intensive care unit (11.29\%). In another study on hemovigilance nursing by Gün et al. (13), the working units of the nurses were as follows: Intensive care unit $(35.0 \%)$, emergency room (6.9\%), internal medicine service (6.9\%), pediatrics service (7.6\%), gynecology service $(6.3 \%)$, general surgery service $(5.8 \%)$ and laboratory $(7.9 \%)$.

Nursing students' knowledge levels were evaluated based on the number of correct answers, and it was found that the range of number of correct answers was $0-13$, and the mean level of knowledge was $4.00 \pm 3.72$. It was found that the number of correct answers for the knowledge level of clinical nurses was between 2 and 13, and the mean of correct answers was $10.36 \pm 2.00$. It was determined that there was a significant difference in terms of the means of the correct answers between nurses and nursing students. This difference led us to conclude that in-service training in the hospital was effective, while nursing students were lacking in education on this subject. It was determined that $64.23 \%$ of the nurses within the scope of the study received hemovigilance training in in-service training. 
Table 1. Comparison of demographic data of nursing students and clinical nurses

\begin{tabular}{|c|c|c|c|c|c|}
\hline \multirow[b]{2}{*}{ Variables } & \multirow[b]{2}{*}{ Groups } & \multicolumn{2}{|c|}{ Nursing student } & \multicolumn{2}{|c|}{ Clinical nurse } \\
\hline & & $\begin{array}{l}\text { Sample } \\
(n=146)\end{array}$ & Percentage (\%) & $\begin{array}{l}\text { Sample } \\
(n=137)\end{array}$ & $\begin{array}{l}\text { Percentage } \\
\text { (\%) }\end{array}$ \\
\hline \multirow{2}{*}{ Gender } & Woman & 131 & 89.73 & 119 & 86.86 \\
\hline & Man & 15 & 10.27 & 18 & 13.14 \\
\hline \multirow{3}{*}{ Class } & $1^{\text {st }}$ class & 47 & 32.19 & & \\
\hline & $2^{\text {nd }}$ class & 40 & 27.40 & - & - \\
\hline & $4^{\text {th }}$ class & 24 & 16.44 & & \\
\hline \multirow{4}{*}{ Work place } & Surgery unit & & & 42 & 30.66 \\
\hline & Internal medicine unit & & & 59 & 43.06 \\
\hline & Intensive care unit & - & - & 19 & 13.87 \\
\hline & Emergency & & & 17 & 12.41 \\
\hline \multirow{3}{*}{ Daily smart device usage } & 6-8 hours & 34 & 23.29 & 25 & 18.25 \\
\hline & $8-10$ hours & 11 & 7.53 & 11 & 8.03 \\
\hline & 10 hours or above & 5 & 3.42 & 0 & 0 \\
\hline \multirow{6}{*}{ Monthly internet usage quota } & $0-2 \mathrm{gb}$ & 6 & 4.11 & 12 & 8.76 \\
\hline & $2-4 \mathrm{gb}$ & 30 & 20.55 & 12 & 8.76 \\
\hline & $4-6 g b$ & 33 & 22.60 & 30 & 21.90 \\
\hline & $6-8 \mathrm{gb}$ & 29 & 19.86 & 17 & 12.41 \\
\hline & $8-10 \mathrm{gb}$ & 18 & 12.33 & 30 & 21.90 \\
\hline & $10 \mathrm{gb}$ or above & 30 & 20.55 & 36 & 26.27 \\
\hline $\begin{array}{l}\text { Do you know about hemovigilance or } \\
\text { hemovigilance nursing? }\end{array}$ & No & 118 & 80.82 & 6 & 4.38 \\
\hline \multirow{6}{*}{ Where did you get this information? } & Internet & 19 & 13.01 & 30 & 21.90 \\
\hline & Undergraduate courses & 8 & 5.48 & 50 & 36.50 \\
\hline & Television & 0 & 0 & 2 & 1.46 \\
\hline & Friend shares & 0 & 0 & 12 & 8.76 \\
\hline & In-service training & 0 & 0 & 88 & 64.23 \\
\hline & Other & 6 & 4.11 & 4 & 2.92 \\
\hline \multirow{2}{*}{$\begin{array}{l}\text { Do you think you have enough } \\
\text { knowledge about hemovigilance? }\end{array}$} & Yes & 3 & 2.05 & 75 & 54.74 \\
\hline & No & 143 & 97.95 & 62 & 45.26 \\
\hline \multirow{2}{*}{$\begin{array}{l}\text { Do you think it is necessary and } \\
\text { important to receive training on } \\
\text { hemovigilance? }\end{array}$} & Yes & 127 & 86.99 & 132 & 96.35 \\
\hline & No & 19 & 13.01 & 5 & 3.65 \\
\hline
\end{tabular}

Table 2. Evaluation of knowledge attitudes of nursing students and clinical nurses

\begin{tabular}{|l|l|l|}
\hline & Mean of correct answers & Correct answers (min-max) \\
\hline Nursing student & $4.00 \pm 3.72$ & $0-13$ \\
\hline Clinical nurse & $10.36 \pm 2.00$ & $2-13$ \\
\hline Min: Minimum, Max: Maximum & & \\
\hline
\end{tabular}


Table 3. Statistics on the average of various variables and correct numbers of nursing students and clinical nurses

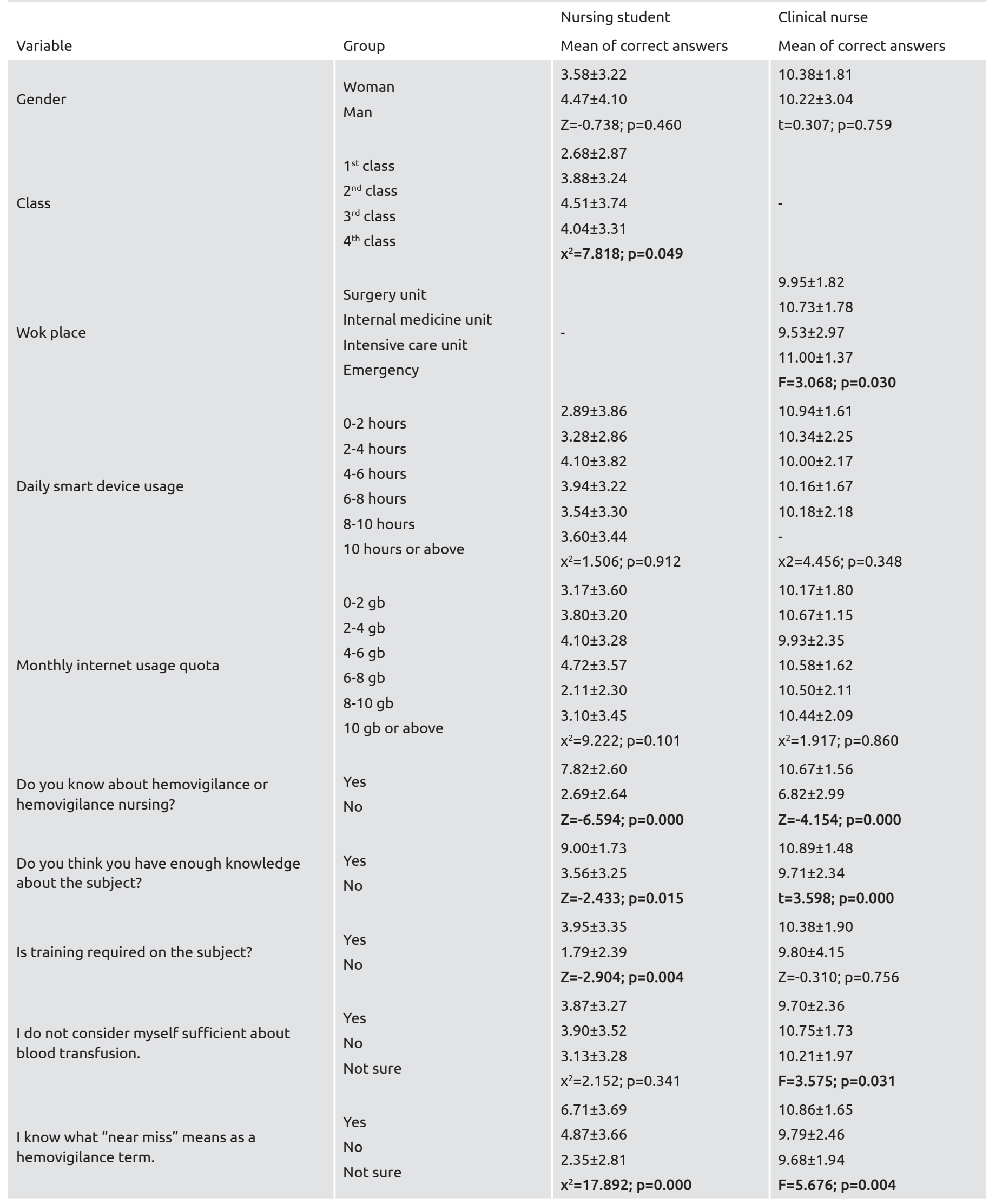


Table 3. contiuned

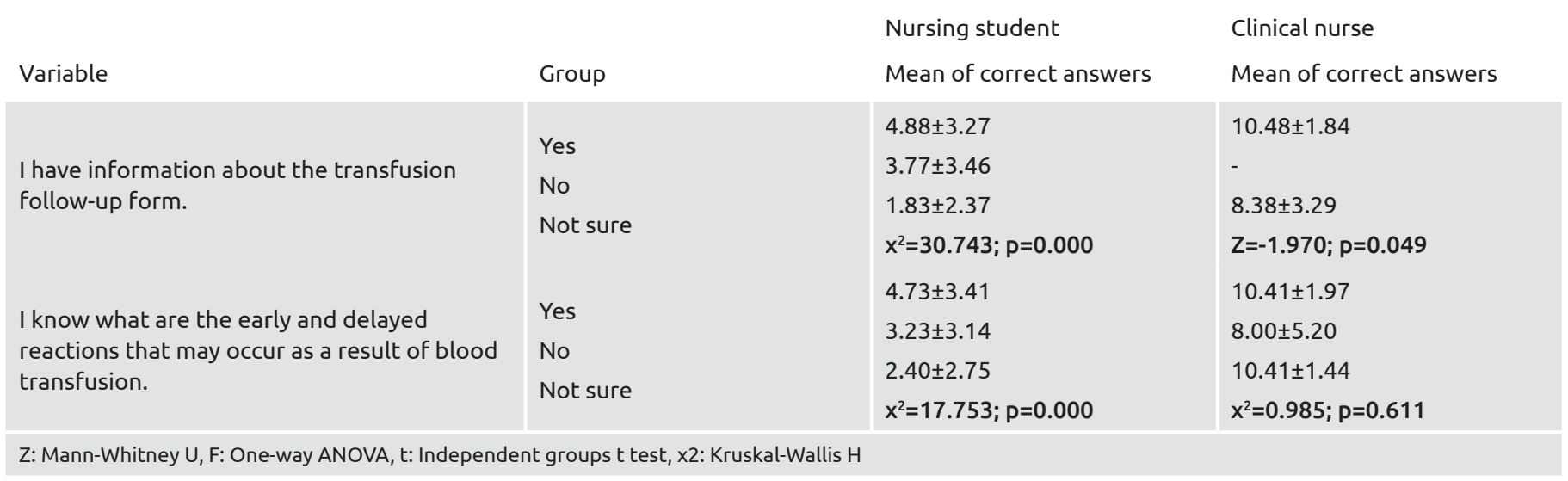

In a study on hemovigilance, the knowledge level of 135 health personnel was evaluated out of 24 points, and they scored $16.30 \pm 3.16$. They concluded that the highest score among the groups belonged to nurses and the lowest score belonged to nursing students (14). In another study, they reported that the scores of the group they worked with (nurse, doctor, other health worker) varied between 1 and 19 (out of 20) and their average was $9.7 \pm 4.2$. In the same study, they found that the mean knowledge of nurses was $10.0 \pm 4.2$ (13). In another study on blood transfusion with midwives in a maternity hospital, the rate of correct answers was found to be between 5\% and $98 \%$, depending on the questions (18). In the study conducted by Shamshirian et al. on nursing students, it was found that only $25.9 \%$ of nursing students had knowledge and awareness about blood transfusion (15). In another study, care standards for hemovigilance were evaluated instead of knowledge level, and as a result, neonatal clinics reported that the compliance rate of nurses working in neonatal intensive care units was 56\% (19).

It was determined that there was a statistically significant difference between the class years and knowledge levels of nursing students $(\mathrm{p}=0.049)$. As a result of the statistics, it was determined that the difference was due to the fact that the knowledge levels of the $3^{\text {rd }}$ and $4^{\text {th }}$ year students were higher than the other students. In our study, it was found that there was a statistically significant difference between the unit they worked in and their level of knowledge $(p=0.030)$. As a result of the statistics, it was determined that the knowledge levels of nurses working in the intensive care unit were lower than the other units. In the study of Gün et al. (13), it was found that there was no significant difference between the working units and the level of knowledge of hemovigilance. In a study conducted in a group of physicians, they reported that those working in the internal medicine achieved highest score and those working in the anesthesia department achieved the second highest score (16). In a study conducted by Rudrappan, it was found that there was no relationship between the clinical experience of the nurse and their knowledge and practices (20). We think that the fact that students take more active roles in the clinic with the following years has a positive effect on their level of knowledge. In the findings, the distribution of in-service training according to the units was examined. As a result, it was determined that only $36.84 \%(n=7)$ of the nurses working in the intensive care unit participated in in-service training. It was determined that more than half of the nurses working in other clinics participated in hemovigilance training. It was thought that the result was due to the low rate of participation in in-service training on hemovigilance.

In our study, it was concluded that there was a significant difference between those who answered "yes" to the question "Do you have information about hemovigilance or hemovigilance nursing?" and those who answered "no" in both groups. The percentage of those who answered this question was $19.18 \%$ among nursing students and $95.62 \%$ among clinical nurses. According to the research sources, it was determined that nursing students obtained the most information about hemovigilance from the internet $\mathrm{t}$, and clinical nurses obtained the most from in-service training. In a study, 55.55\% of the doctors and $9.09 \%$ of the nurses who participated in the study reported that they knew the term hemovigilance (21). In a study by Aneke et al. (22), it was reported that the majority of the participants were not aware of the transplant units or committees for hemovigilance. In the literature, when the nurses were questioned whether they participated in training programs such as in-service training and seminars related to hemovigilance, $9.24-10 \%$ of them stated that they participated $(23,24)$. In the study of Jimenez-Marco et al. (17), 76.03\% of the nurses stated that they did not receive any formal training on transfusion before starting to work at the workplace, and that $83.75 \%$ of the nurses did not receive inservice training during their work in their hospitals. Unlike the literature, the clinical nurses participating in our study received in-service training on the subject with a rate of $64.23 \%$. In our study, the insufficient knowledge of nursing students on this subject made us think that it was not included in the core curriculum followed in undergraduate nursing programs in our country. Given that the most common source for student nurses to learn about hemovigilance was the internet, it was believed that they could obtain insufficient, incomplete and incorrect information from the internet.

The question "Do you think you have enough knowledge about the subject?" was directed to the participants of the study. It was found that the knowledge levels of the group who 
answered "yes" to the questions "I know what "near miss" means as a hemovigilance term" and "I have information about the transfusion monitoring form" were statistically significant in both groups $(\mathrm{p}<0.05)$. It was determined that the knowledge level of the group who answered "yes" was higher. In line with this result, it was thought that the group who thought that they had inadequate knowledge on the subject could increase their awareness on this issue. At the same time, with this result, it was determined that individuals could correctly identify their deficiencies in terms of knowledge and were aware of these deficiencies. In a study where nurses were asked a different question "Do you think the reactions are dangerous?", 70\% of the nurses answered "yes" to the question (25). In the study of Jimenez-Marco et al. (17), it was found that nurses who received transfusion training felt that they had a better level of knowledge than those who did not receive training. It was found that the level of knowledge of those who answered "yes" to the statement "I don't have enough knowledge about blood transfusion" was lower than those who answered "no". In line with the literature, this result suggests that the level of knowledge of nurses affects their self-confidence in practice.

In our study, it was questioned whether education about hemovigilance was necessary. Of the students, $86.99 \%$ and $96.35 \%$ of the nurses reported that they thought education was necessary and important. At the same time, it was found that there was a significant difference between the knowledge levels of nursing students who answered "yes" to this question and those who answered "no" $(\mathrm{p}=0.004)$. There was no significant difference in nurses. In a study conducted with midwives, their knowledge of blood transfusion was questioned, and $99.2 \%$ of midwives reported that education was necessary (18). In another study, 63\% of nurses reported that they had participated in a blood bank training program before (20). In the studies in the literature, the effects of the education on the level of knowledge were evaluated by making a pre- and post-education evaluation, and they found that the trainings were effective and positive $(13,26)$. Raising awareness about hemovigilance through inservice training will lead to improved reporting of transfusion reactions (23). Most of the graduates have a positive attitude towards transfusion reaction reporting, but their knowledge of the hemovigilance program is weak and the reporting procedure is less common in recent graduates (24). Reporting and data collection should not be the sole purpose of the hemovigilance system, and the use of hemovigilance data sources in practice may be beneficial to increase transfusion safety (17).

\section{Study Limitations}

The groups compared in our study were studied as a single center in their own universe. The universe was accepted as a sample and all individuals who voluntarily agreed to participate in the study were included in the study. Therefore, power analysis was not performed. One of the limitations of our study was that our results could only be generalized to the sample group.

\section{Conclusion}

It was determined that clinical nurses had a high level of knowledge about hemovigilance, while students did not. It was concluded that as the clinical experience of nursing students increased, the level of knowledge increased. The database in which both groups used for research was determined as any website after Google scholar. Due to the low level of hemovigilance knowledge of nursing students, necessary studies can be done to include this subject in the nursing education curriculum. It is recommended to support nurses with continuous training after graduation in terms of the directly proportional development of behavior, attitude and clinical skills. It is thought that in-service trainings are functional in this regard, and their awareness and knowledge about hemovigilance will increase by working integrated with the clinic and including nursing students in in-service training. The applicability of the HII was found to be effective, but it was recommended to update it in terms of measurement and evaluation and develop a fully structured scale in similar groups.

\section{Ethics}

Ethics Committee Approval: In order to carry out the research, permission was obtained from the institution where the study was conducted and approval from the Ankara Yildırım Beyazit University Ethics Committee (29.05.2019/decision no: 51) was obtained.

Informed Consent: Obtained.

Peer-review: Externally peer reviewed.

\section{Authorship Contributions}

Concept: A.K., E.T., Design: A.K., E.T., Data Collection or Processing: A.K., E.T., Analysis or Interpretation: A.K., E.T., Literature Search: A.K., E.T., Writing: A.K., E.T.

Conflict of Interest: No conflict of interest was declared by the authors.

Financial Disclosure: The authors declared that this study received no financial support.

\section{References}

1. Transfüzyon öncesi uygunluk testleri. In: Uluhan R, Berkem R, Emekdaş G, Bayık M, editors. Temel Kurs kitabı. 1st ed. İstanbul, Şan Ofset. 2010:76-84.

2. T.C. Sağlık Bakanlığı. Ulusal Hemovijilans Rehberi. 2016:6.

3. Whitaker BI, Belov A, Anderson SA. Progress in US hemovigilance: can we still learn from others? Transfusion 2019;59:433-6.

4. European Union. Directive 2002/98/EC of the European Parliament and of the Council of 27 January 2003 setting standards of quality and safety forthe collection, testing, processing, storage and distribution of human blood and blood component sandamending Directive 2001/83/EC. Official Journal of the European Union 2003;33:30.

5. Atilla E, Arslan Ö. Hemovigilance. Türkiye Klinikleri HematologySpecial Topics 2013;6:7-15. 
6. de Vries RR, Faber JC, Strengers PF; Board of the International Haemovigilance Network. Haemovigilance: an effective tool for improving transfusion practice. Vox Sang 2011;100:60-7.

7. Chew E, Benjamin RJ, McDonald CP, Wiersum-Osselton JC, WoodEM, International Society of Blood Transfusion Working Parties on Transfusion-Transmitted Infectious Diseases (Bacterialsubgroup) and Haemovigilance. International survey on definitions and current practices in prevention, diagnosis, management and reporting of transfusion-transmittedbacterialinfections. ISBT Science Series 2015;10:31-40.

8. T.C. Erciyes Üniversitesi Sağlık Uygulama ve Araştırma Merkezi. Hemovijilans Kapsamında Kan ve Kan Ürünlerinin Transfüzyon Endikasyonları ve Transfüzyon Reaksiyonlarına Yaklaşım Kılavuzu. Temmuz 2017.

9. T.C. Sağlık Bakanlığı. Ulusal kan ve kan ürünleri rehberi. Türkiye Kan Merkezleri ve Transfüzyon Derneği, Çesa Basım Hizmetleri 2011:1-329.

10. Steinsvåg CT, Espinosa A, Flesland Ø. Eight years with haemovigilance in Norway. What have we learnt? Transfus Apher Sci 2013;49:54852.

11. Reesink HW, Panzer S, Gonzalez CA, Lena N, Muntaabski P, Gimbatti $S$, et al. Haemovigilance for the optimal use of blood products in the hospital. Vox Sang 2010;99:278-93.

12. Ait Bouchrim SA, Haddad A, Bou Assi T, Oriol P, Guyotat D, Bois C, et al. Residents' knowledge in transfusion medicine and educational programs: A pilot study. Transfus Clin Biol 2020;27:18-24.

13. Gün R, Öz S, Altındiş S, Uyutan Y, Köroğlu M, Altındiş M. Hemovijilans hemşireliği ve transfüzyon güvenliğine katkısı. Turk Hij Den Biyol Derg 2019;76:405-14.

14. Jafari E, Koohestani S, Ghaziizade M. Knowledge among health care workers about hemovigilance in hospitals of Kerman in 2018. Scientific Journal of Iran Blood Transfus Organ 2019;16:280-8.

15. Shamshirian A, Alirahimi Z, Ghorbanpour A, Motamen S, Maadi N, Zamani P, et al. Knowledge and Awareness of Nursing Students on Blood Transfusion. Int J Med Invest 2017;6:129-34.

16. Philip J, Kumar S, Chatterjee T, Mallhi RS. Knowledge of Transfusion Medicine Among Resident Doctors in Clinical Specialities: A CrossSectional Study from a Tertiary Care Centre. Indian J Hematol Blood Transfus 2015;31:374-7.
17. Jimenez-Marco T, Clemente-Marin G, Girona-Llobera E, Sedeño M, Muncunill J. A lesson to learn from Hemovigilance: The impact of nurses' transfusion practice on mistransfusion. Transfus Apher Sci 2012;47:49-55.

18. Grolleau N, Liétard C, Lebdiri B, Le Niger C. Évaluation des connaissances transfusionnelles des sages-femmes dans les maternités publiques et privées de la région Bretagne en 2014 [Evaluation of midwives transfusion knowledge in Brittany public and private maternities, 2014]. Transfus Clin Biol 2015;22:318-25.

19. Tajalli S, Nourian M, Rassouli M, Baghestani AR. Clinical assessment of nursing care regarding hemovigilance in neonatal wards and neonatal intensive care units in selected hospitals affiliated to Shahid Beheshti University of Medical Sciences (2013-2014). Iranian Red Crescent Medical Journal 2015;17:e19987.

20. Rudrappan RB. Evaluating the knowledge and practices of nurses and paramedics in blood transfusion services-A survey in thestates of Tamil Nadu and Pondicherry, India. J Educ Health Promot 2019;8:48.

21. Sireesha N, Reddy KP, Sravani J, Rani S, Rathinavelu M. Assessment of Healthcare Professional Awareness towards Haemovigilance (HvPI) Programme of India in South India. IOSR JPBS 2015;10:13-7.

22. Aneke JC, Ezeama N, Okocha CE, Onyeyili AN, Onah CE, Ibeh $\mathrm{NC}$, et al. Knowledge, attitude and practice of haemovigilance among health care professionals in a Nigerian Tertiary Hospital. The Egyptian Journal of Haematology 2017;42:108.

23. Shivgunde PP, Besekar SM, Bhojwani KM, Bhojwani DG. Knowledge, attitude and practice of haemovigilance amongst healthcare professionals in Nashik, Maharashtra, India. International Journal of Basic \& ClinicalPharmacology 2018;7:986.

24. HimaBindu K, Sudha J. Knowledge, attitude, perception of Hemovigilance among post-graduates in tertiary care hospital, King George Hospital, Visakhapatnam, Andhra Pradesh.IOSR Journal of Dental and Medical Sciences 2020;19:28-31.

25. Roshi, Tandon VR. Knowledge, attitude and practices about hemovigilance among practitioners: a cross-sectional study. International journal of basic and clinical pharmacology 2019;8:25536.

26. Mirzaee MS, Karimi M. The Assessment of the Effect of the Haemovigilance Education by the Conceptual Map on the Knowledge of Nursing Students. Pajouhan Scientific Journal 2018;17:51-6. 